\title{
Teaching Methodology and Motivation: Comparison of Iranian English Private Institute and High School
}

\author{
Mahbube Keihaniyan \\ Islamic Azad University, Najafabad Branch, Iran \\ Email: m_keihaniyan@yahoo.com
}

\begin{abstract}
This study investigated 50 state high school and private institute learners in Najafabad, 25 each, to see if there was any relationship between teaching methodology and motivation. First, 100 students were selected randomly. A Nelson test was administered to the students to select and homogenize the intended number of students for the study. Next, 50 students $(25$ from the state high school and 25 from the private institute, whose scores on the Nelson test were between one standard deviation above and one standard deviation below the mean) were selected to answer a motivation questionnaire. The analysis of the results gained through the check lists about teacher's role, learner's role, teaching objectives and teaching activities, showed that the teaching methodology in these settings was different. While high school teachers were at the center of the classroom; learners in the private institute had an active role in the learning process. Task based, realia and audio visual materials are common in the private institute but text based materials are common in the high school. The focus of teaching activities in the private institute is on different kinds of skills and drills. In the high school practice on different kinds of imitations and drills are common activities. Oral skills, practice on fluency, and accuracy are common objectives in the private institute. In the high school, the focus is on language components (grammar and vocabulary).Although there was no significant difference between these two groups with regard to proficiency, the analysis of the learner's responses to the motivation questionnaire showed that the private institute learners were more motivated to learn English than the high school learners. The findings of this study are useful for teachers to apply motivated methods to improve learners' motivation. Also, students who take responsibility for their learning enjoy freedom and power to make decisions in their learning. Knowing that learning is a product of one's own activities, a student feels more rewarded and enhances his courage to get involved in an active learning process.
\end{abstract}

Index Terms - motivation, teaching methodology, task based, Realia, audio visual materials, private institute, Nelson Test

\section{BACKGROUND}

Language teaching came into existence as a profession in the twentieth century. Its foundation was developed during the early part of the twentieth century, as applied linguists focused on the fields of linguistics and psychology to support what was thought to be a more effective teaching methodology. Language teaching in the twentieth century was characterized by frequent changes, innovations and development of language teaching ideologies (Richards \& Rodgers, 2003).

Method- a systematic set of teaching practices based on a particular theory of language and language learning- is a powerful concept, and the quest for better methods has been a preoccupation of many teachers throughout the twentieth century (Richards \& Rodgers, 2003).

As methods link theory and practice, they represent a contribution of applied linguistics to language education. Methods do not necessarily arise from a priori theorizing, they could be derived from successful practice (Krashen, 1987). Richards and Rodgers (1986, 2001, as cited in Davies, 2006) describe methods in terms of three levels: approach, design, and procedure. Approach refers to the underpinning theory of language and language learning. Design covers the specification of linguistic content, the role of teacher and learners, and instructional materials. Procedure means the techniques and activities that are used in the classroom.

Despite the claims of proponents of some methods, no consensus has emerged as the best way to teach a language; there have been some ideas to abandon what Richards (2002, as cited in Davies, 2006) calls the supermethod and to concentrate on equipping teachers with a repertoire of methods and skills that can be used in different contexts.

The general consensus is to consider methods as sociocultural products, that is, the products of their times. In fact no method is inherently superior to another; instead, some methods are more appropriate than others in a particular context (Adamson, 1988).

\section{A. Motivation}


At the turn of the twentieth century there has been an uprising interest in the investigation of the role of learner's characteristics in a foreign and second language learning (hereafter referred to as FLL/SLL) process (Brown, 2000). A major trend in language syllabus design has been the use of information from learners on curriculum decision-making (Nunan 1993). Students should be active agents of their learning, not merely passive receivers of information. Learning is a product of learners' own actions and is based not only on the learners' prior skills and knowledge but also on their experience and interest. If learners have role in defining and choosing the goals, the course content, and methodology, learning will be more relevant to them (Decorte, 1993).

In order to create a learning environment in which students' needs are addressed, teachers need to understand their students' interests and concerns, in short, their motivation. If considering preferences felt by learners is crucial for effective language learning, negotiation is needed between teachers and students. Information has to be exchanged about the role of teacher and learners, so that compromises are reached between what learners want and what the teacher can provide (Brindly, 1989).

Although many teachers admit that learners differ in terms of needs and preferences, they may not consult learners in conducting language activities. The basis for such reluctance to cooperate may be that learners are not capable to express what they need to learn and how they want to learn it.

Many research projects suggest a meaningful relationship between motivation and student's performance. Schmidt (1993) argues that motivated learners are more likely to pay close attention to the language input than those who are not so motivated. Niezgoda and Rover (2001) suggested that motivation might influence English learners' sensitivity to grammatical errors. Cook (2001) also points out that highly motivated learners can notice pragmatic functions of language. A similar observation was made by Tateyama (2001) who found that highly motivated learners showed a better performance in a role-play (Csizer \& Dornyei, 2005).

One of the influential studies of student motivation was conducted by Robert Gardner and Wallace Lambert (1972). During 12 years they studied Foreign Language Learning in Canada, the United States, and the Philippines in order to investigate how attitude and motivation affect success in language learning. They identified two types of motivation: instrumental and integrative.

Instrumental motivation refers to motivation to learn a language in order to reach instrumental goals: promoting a job, reading technical material, translation and so on.

In integrative motivation learners wish to integrate himself/herself into the culture of the second language group, to identify with them, and become a part of the target language society. Many of Lambert studies (1963) found that higher scores on proficiency test in a Foreign Language followed integrative motivation. In a number of previous studies, positive attitudes toward learning English was found to be one of the most important factors in a motivated behavior (Crooks \& Schmidt, 2000). If learners have a positive attitude toward learning a second or foreign language, they are more motivated to learn that language.

In summary, literature suggests that most learners begin their academic career with integrative and instrumental motivation toward achievement (Entwisle et al., 1986; Stipek \& Ryan, 1997).

\section{B. Statement of the Problem}

Teaching methodology plays a significant role in the EFL learning process, and most learners may feel disappointed if the method of teaching is not appropriate for them.

Regarding language teaching in Iran, Bakhshi (1997) notes: "One of the problems is an old belief that just knowing about the language and its grammatical patterns suffice teaching English, so there are no rooms left for advancement through insight of linguistics, psycholinguistics, sociolinguistics, methodology, and pedagogy" (p.14). It seems that one of the deficiencies is that most teachers lack sufficient knowledge of various methods and skills to implement them. Teachers do not use classroom activities that increase students' commitment for learning English .This makes students feel reluctant to the task of learning. In other words, if teachers base their methodologies only on cognitive considerations, they would neglect the psychological aspect of human behavior. So, language teachers must be aware of the psychological state of learners (motivation \& needs) to understand the affective condition for learning.

One of the few research works that sheds light on the relationship between teaching methodology and motivation was done by Ferando et al (1999). They found if teachers employed a suitable methodology, students' motivation would increase and they could perform better on exams. This study attempts to investigate this issue in an Iranian context. In this study, the researcher wants to compare teaching methodology and motivation in the high school and the language institute because these factors are different in these two setting. In the high school teacher has the central role but in the private institute learners have central role and in the private institute learning English is an optional course but an obligatory one in the high school then the researcher wants to find the relationship between teaching methodology and motivation.

\section{Objectives of the Study}

The importance of testing in educational setting necessitates the investigation of its relationship with various factors involved in the process of teaching. Therefore, the present study was designed to show if there is any relationship between teaching methodology and student's motivation. Methodology has been defined differently by scholars but, in this study, it is defined in terms of teacher's role, student's role, teaching materials, teaching activities, and teaching 
objectives based on Richards and Rodgers (2003). High school and English language institute were selected as two places, where different approaches to the above mentioned factors, were expected to be founded. Consequently, it was decided to see what teachers do in each setting, and then to see if there was any relationship between methodology and motivation in each setting. The objectives of the study are restated in the following research questions and null hypotheses.

\section{PROCEDURES}

\section{A. Research Questions}

With regard to what has been presented above, the present research will address five major questions:

1. Is the methodology used in high school different from the methodology used in English language institute in terms of teacher's role, student's role, teaching materials, teaching activities, and teaching objectives?

2. If the answer to the first question is positive, is there any difference between learners' motivation in high school and English language institute?

3. Dose the teaching methodology have any relationship with the type of motivation (instrumental and integrative)?

\section{B. Significance of the Study}

Motivation and teaching methodology are important factors in language learning. Teachers should be aware of the relationship among these variables. In sum, this study is expected to enrich knowledge of English teachers about the relationship between teaching methodology and motivation and help them to handle test anxious students more skillfully.

\section{Participants}

The participants of this study ranged from 15 to 17 year-old students selected randomly from 50 high school female students and 50 female students studying English as a foreign language (EFL) in a private English institute in Najafabad Learners in these two settings enrolled in the second grade and their major was computer. Since the number of students in each class in both settings was 25 , the participants were selected from two classes with the same teacher and setting. Then, a Nelson test was administered to the students to select and homogenize the intended number of students for the study. Next, 50 students, 25 from Mahjub high school and 25 from Parto private institute, whose scores on the Nelson were between one standard deviation above and one standard deviation below the mean, were selected to take part in the study; to answer questions of a motivation questionnaire. Care was taken to choose those high school students who were not studying in the language institute simultaneously.

\section{Instruments}

Data in this study were collected through using instruments as follows:

1) A Nelson test (1999, as cited in Dadkhah's thesis, 2002). It consisted of 40 multiple-choice items on grammar and vocabulary to estimate the proficiency level of the learners. The validity of the test was established by consulting with my supervisor and advisor (see Appendix A for a copy).

2) A set of checklists to identify similarities and differences between teaching methodologies in the high school and the private institute. They were prepared by the researcher based on Richards and Rodgers (2003). The checklists consisted of teacher's role (Appendix B), learner's role (Appendix C), materials of the course (Appendix D), teaching activities (Appendix E), and teaching objectives (Appendix F), were used when the researcher and two other observers observed the English classes in the high school and the private institute for three sessions. The observers' duty was to observe the procedures of the classrooms including the role of teacher, role of learners, materials used in the class, objectives of the course pursued by the teacher and activities used in the class to identify similarities and differences between teaching methodology in these two settings. The checklists were to be filled by each of the three observers.

3) A motivation test. It was developed by Celce Murcia (1991) and consisted of 41 questions in six parts. Part one consisted of eight questions dealing with the view of participants regarding the reasons for learning English. Part two consisted of five questions to measure students' attitude toward learning English. Part three consisted of seven items to measure students' attitude about the English textbooks. Part four consisted of one question to rate the extent of students' satisfaction with achievement in English. Part five consisted of 17 items to measure the students' attitude toward the preferred ways and activities for learning English. Part six consisted of three items to rate the extent to which students agree with the way of error correction. This questionnaire was translated into Farsi to avoid participants' confusion. According to Seliger and Shohamy (1989), one of the main problems with questionnaires in a foreign language (FL) is that participants often have problems in providing answers in FL and there is no assurance that the questions are properly understood and answered correctly. Also, the participants of this study were in the second grade and not proficient enough in English; therefore, this questionnaire was used in Farsi, the native language of the participants.

The validity of the test was measured by consulting with my supervisor and advisor and the researcher measured its reliability via Cronbach's alpha $(\mathrm{r}=0.81)$. The participants were asked to rate their attitudes on a 5-point Likert scale (see Appendices H \& I for a copy). 
Data were collected through the following stages: At first 100 students from the high school and the private institute, 50 each, were selected randomly. Then, via the administration of the Nelson test, 50 students (25 from the high school and 25 from the private institute) were selected as the participants of the study. Then the motivation questionnaire was distributed among the participants. They were asked to read the questions carefully and express their feeling by choosing one of the alternatives written in front of each statement. They were told nothing about the aim of the study to avoid halo effect. Also it was optional for the students to write their names at the top of the papers. The selected students were tested in terms of the relationship between teaching methodology and motivation.

\section{RESULTS AND ANALYSIS}

\section{A. The Results of the Analysis of the Observers' Responses to the Checklists}

The Results of the Analysis of the Observers' Responses to the checklists of teachers` Role, learners' role, teaching materials, teaching activities, and teaching objectives will be presented.

The Results of the Analysis of the Observers' Responses to the Teachers' Role Checklist

Table 1 gives a summary of the observers' findings for both groups, that is, the high school (group1) and the private institute (group2) classrooms, on the teachers' role checklist, and Figure 1 gives the graphical representation of the same results.

TABLE 1.

DESCRIPTIVE STATISTICS OF THE TwO GROUPS ON THE TEACHERS ROLE CHECKLIST

Group Statistics

\begin{tabular}{|ll|r|r|r|r|}
\hline & group & $\mathrm{N}$ & \multicolumn{1}{c|}{ Mean } & Std. Deviation & $\begin{array}{c}\text { Std. Error } \\
\text { Mean }\end{array}$ \\
\hline teacher as a facilitator & 1 & 16 & .25 & .447 & .112 \\
and a counselor & 2 & 16 & 1.25 & 2.236 & .559 \\
\hline teacher as having & 1 & 16 & 3.06 & 2.265 & .566 \\
central role & 2 & 16 & 2.63 & 1.668 & .417 \\
& & & & & \\
\hline
\end{tabular}

As Table1 shows, the mean and the standard deviation scores for teacher as a facilitator and a counselor in the private institute are respectively 1.25 and 2.23 . The mean and the standard deviation score of the central role for the teacher in the high school are respectively 3.06 and 2.26. By comparing the means of the two groups shown in the above table it can be said that the teacher in the high school has the central role in the classroom and decides what to teach and how to teach but in the private institute, she is as a facilitator and counselor in the class. Figure 1 shows the graphical representation of the teachers' role in the high school and the private institute.

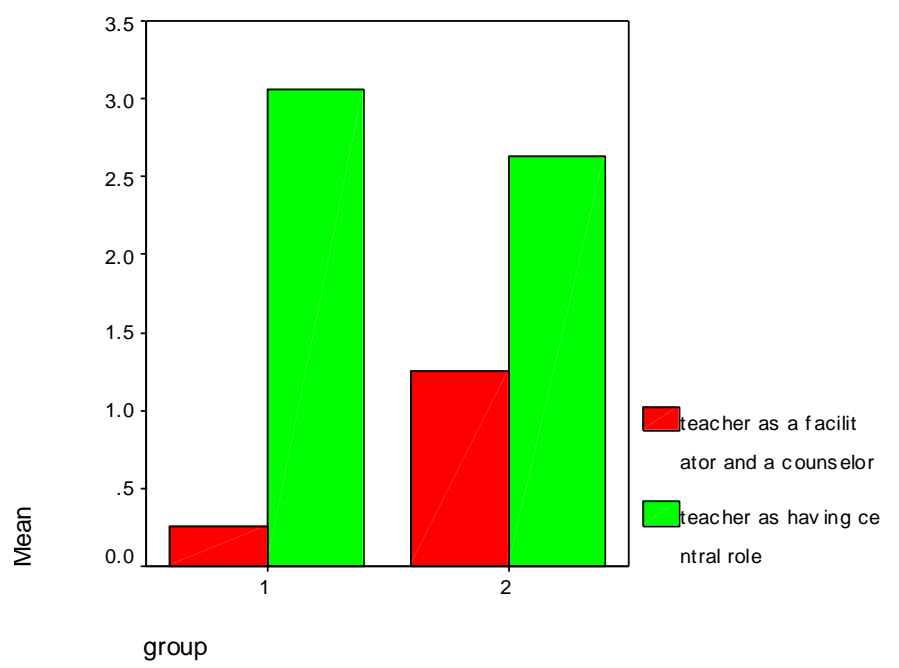

Figure 1. Graphical representation of the teachers' role in the high school and the private institute

Figure1 represents the mean differences of the teacher s`role in the high school and the private institute. In the private institute teachers are as facilitator and counselor for their learners but they have central role in the high school.

The Results of the Analysis of the Observers' Responses to the Learner s'Role Checklist

Table2 gives a summary of the observers' findings for both groups on the learners' role checklist, and Figure 2 gives the graphical representation of the same results. 
TABLE 2.

DESCRIPTIVE STATISTICS OF THE TWO GROUPS ON THE LEARNERS ROLE CHECKLIST

Group Statistics

\begin{tabular}{|ll|r|r|r|r|}
\hline & GROUP & $\mathrm{N}$ & Mean & Std. Deviation & $\begin{array}{c}\text { Std. Error } \\
\text { Mean }\end{array}$ \\
\hline active & high school & 9 & 2.00 & 2.598 & .866 \\
& language institution & 9 & 6.33 & 7.566 & 2.522 \\
\hline passive & high school & 9 & 8.33 & 7.906 & 2.635 \\
& language institution & 9 & 3.67 & 3.905 & 1.302 \\
\hline
\end{tabular}

As Table 2 shows, the mean and the standard deviation scores for active role of learners in the private institute are respectively 6.33 and 7.566. The mean and the standard deviation scores for passive role of learners in the high school are respectively 8.33 and 7.90. By comparing the means of the two groups shown in the above table, it can be said that learners have an active role in the private institute but a passive role in the high school. Figure 2 gives the graphical representation of the learners' role in the high school and the private institute.

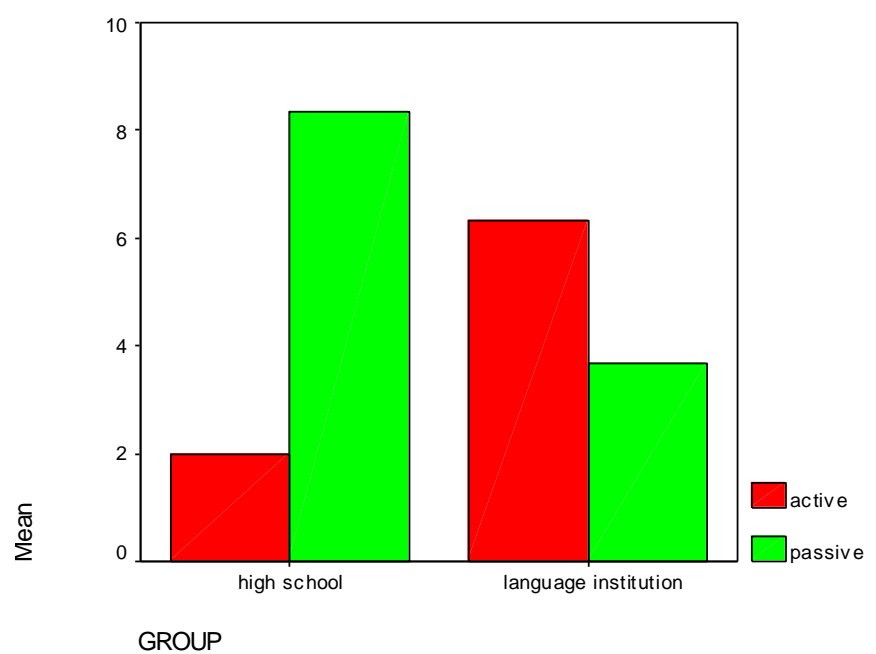

Figure 2. Graphical representation of the learners' role in the high school and the private institute

Figure 2 shows the mean differences of the learners' role in the high school and the private institute. In the private institute learners have active role but they are passive in the high school.

\section{The Results of the Analysis of the Observers' Responses to the Material Checklist}

Table 3 gives a summary of the observers' findings for both groups, that is, the high school and the private institute classrooms, on the material checklist. Figure 3 gives the graphical representation of the same results.

TABLE 3.

DESCRIPTIVE STATISTICS OF THE TWO GROUPS ON THE MATERIAL CHECKLIST

Group Statistics

\begin{tabular}{|ll|r|r|r|r|}
\hline & group & $\mathrm{N}$ & Mean & Std. Deviation & $\begin{array}{c}\text { Std. Error } \\
\text { Mean }\end{array}$ \\
\hline task based materials & high school & 5 & .20 & .447 & .200 \\
& language institution & 5 & 1.00 & 2.236 & 1.000 \\
\hline using realia & high school & 5 & .20 & .447 & .200 \\
& language institution & 5 & 1.00 & 2.236 & 1.000 \\
\hline text based materials & high school & 5 & 1.00 & 2.236 & 1.000 \\
& language institution & 5 & .80 & 1.789 & .800 \\
\hline audio visual materials & high school & 5 & .40 & .548 & .245 \\
& language institution & 5 & 2.00 & 2.739 & 1.225 \\
\hline
\end{tabular}

As Table 3 shows, the mean scores of task based, realia and audio visual materials in the private institute are respectively $1.00,1.00$ and 2.00 . The mean of text based materials in the high school is 1.00 . By comparing the means of the two groups shown in the above table it can be said that task based, realia and audio visual materials are common in the private institute but text based materials are common in the high school. Figure 3 gives the graphical representation of the materials used in the high school and the private institute. 


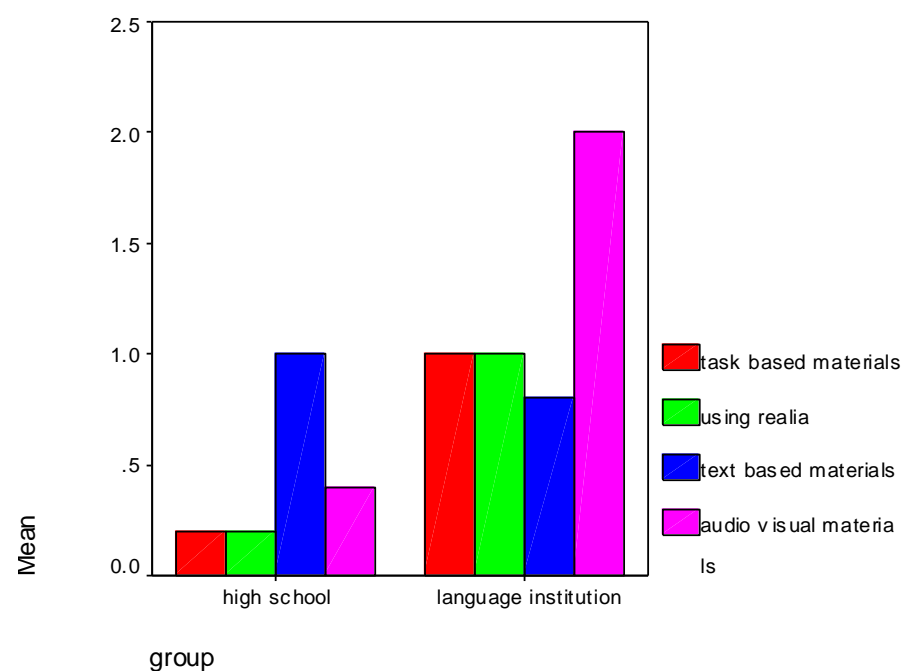

Figure 3: Graphical representation of the materials in the high school and the private institute

Figure 3 represents the mean differences of the materials in the high school and the private institute. In the high school, text based materials are common but in the language institute, realia, audio visual, and task based materials are more used.

\section{The Results of the Analysis of the Observers' Responses to the Teaching Activities Checklist}

Table 4 gives a summary of the observers' findings for both groups, that is, the high school and the private institute classrooms, on the teaching activities checklist, and Figure 4 gives the graphical representation of the same results.

TABLE 4.

Descriptive Statistics of the Two Groups on the Teaching Activities

\begin{tabular}{|ll|r|r|r|c|}
\multicolumn{7}{|c}{ Group Statistics } \\
\hline & group & \multicolumn{1}{|c|}{$\mathrm{N}$} & \multicolumn{1}{c|}{ Mean } & Std. Deviation & $\begin{array}{c}\text { Std. Error } \\
\text { Mean }\end{array}$ \\
\hline different drills & 1 & 22 & 2.73 & 1.956 & .417 \\
& 2 & 22 & 3.09 & 1.540 & .328 \\
\hline
\end{tabular}

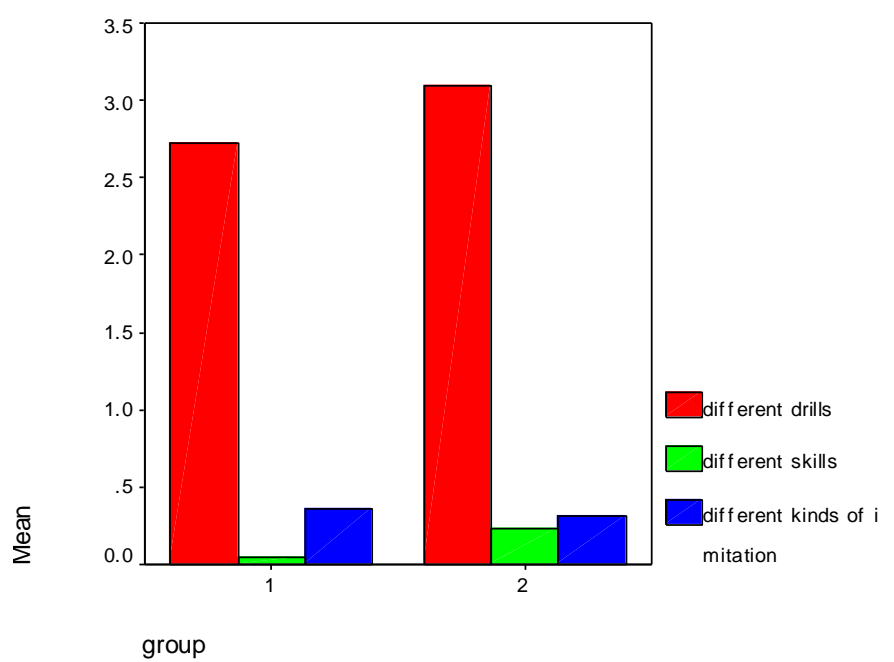

Figure 4: Graphical representation of the teaching activities in the high school and the private institute

As Figure 4 shows, the focus of teaching activities in the private institute is on different kinds of skills (listening, speaking, reading, writing) and drills (elicitation, restatement, replacement,...). In the high school practice on different kinds of imitations (choral and individual imitation) and drills are common activities.

The Results of the Analysis of the Observers' Responses to the Teaching Objectives Checklist

Table 5 gives a summary of the observers' findings for both groups on the teaching objectives checklist, and Figure 5 gives the graphical representation of the same results. 
TABLE 5.

DESCRIPTIVE StATISTICS OF THE Two GROUPS ON THE TEACHING OBJECTIVES CHECKLIST

Group Statistics

\begin{tabular}{|ll|r|r|r|r|}
\hline & group & $\mathrm{N}$ & Mean & Std. Deviation & $\begin{array}{c}\text { Std. Error } \\
\text { Mean }\end{array}$ \\
\hline oral skills & high school & 15 & .27 & .458 & .118 \\
& language institution & 15 & 1.67 & 2.440 & .630 \\
\hline language components & high school & 15 & .67 & 1.345 & .347 \\
& language institution & 15 & 1.47 & 2.200 & .568 \\
\hline
\end{tabular}

As Table 5 shows, the mean and the standard deviation scores on oral skills (speaking and listening) in the private institute are respectively 1.67 and 2.44. The mean and the standard deviation scores of language components (vocabulary and grammar) in the high school are respectively 1.47 and 2.20. By comparing the means of the two groups shown in the above table it can be said that command of oral skills are common in the private institute but command of language components, such as vocabulary and grammar are common in the high school. Figure 5 gives the graphical representation of the teaching objectives in the high school and the private institute.

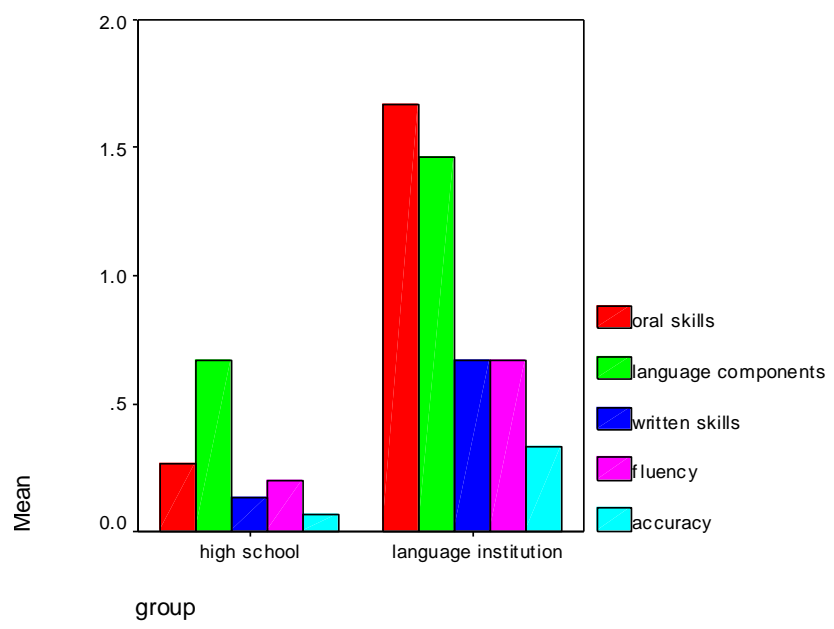

Figure 5: Graphical representation of the teaching objectives in the high school and the private institute

Figure 5 represents the mean differences of the teaching objectives in the high school and the private institute. As this figure shows oral skills, practice on fluency, and accuracy are common in the private institute. In the high school, the focus is on language components (grammar and vocabulary).

Teaching methodology consists of the role of teacher, the role of learners, teaching objectives, teaching activities and materials used in the classroom (Richard and Rodger, 2003). According to these tables and graphs, it is clear that teaching methodologies are different in the high school and the private institute.

\section{B. The Analysis of the Learners' Responses to the Motivation Questionnaire and the Relationship between Teaching Methodology and Motivation}

Table 6 gives a summary of the findings for both groups, that is, the high school and the private institute learners, on the motivation questionnaire, and Figure 6 presents the graphical representation of the same results.

TABLE 6.

DESCRIPTIVE STATISTICS OF THE TwO GROUPS ON THE MOTIVATION QUESTIONNAIRE

\begin{tabular}{|c|c|c|c|c|c|c|c|c|c|}
\hline \multicolumn{5}{|c|}{ High School } & \multicolumn{5}{|c|}{ Language Institute } \\
\hline Min & Max & Mean & SD & variance & Min & Max & Mean & SD & variance \\
\hline 99 & 205 & 183.08 & 20.845 & 434.493 & 153 & 230 & 195.24 & 18.622 & 346.773 \\
\hline
\end{tabular}

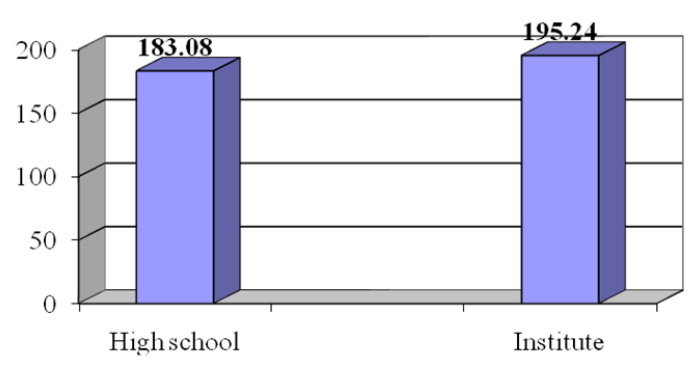

Figure 6. The graphical representation of the results for the motivation questionnaire 
As Table 6 shows, the mean and the standard deviation scores of the high school students on the motivation test are respectively 183.08 and 20.84. For the language institute students the mean and the standard deviation scores are 192.24 and 18.62 respectively. In the high school group, the highest score and the lowest score are 205 and 99 , but in the private institute the highest score is 230 and the lowest score is 153 . The above table shows that the mean score for the motivation obtained by the language institute students is higher than that obtained by the high school learners.

In order to find out whether or not this difference is statistically significant, a $t$-test was run. Table 7 shows the results of this $t$-test.

TABLE 7.

THE RESUlTS OF THE T-TEST FOR THE MOTIVATION QUESTIONNAIRE

\begin{tabular}{|l|l|l|l|l|l|l|l|}
\hline THE RESULTS OF THE T-TEST FOR THE MOTIVATION QUESTIONNAIRE \\
\hline Group & No. & Mean & SD & SEM & df & t & $\mathrm{p}$ \\
\hline High School & 25 & 183.08 & 20.845 & 4.169 & 48 & -2.229 & .031 \\
\hline
\end{tabular}

Table 7 reveals that the amount of $t$-observed $(t=-2.229)$ is significant at the probability level of $\mathrm{p}=.031$, which is smaller than .05. In other words, motivation is significantly higher for the language institute students than for the high school students. In the previous part, it was identified that teaching methodologies were different in these two settings then it seems there is a relationship between teaching methodology and motivation.

\section{The Results of the Analysis of the Learners' Responses to Different Parts of the Motivation Questionnaire}

The motivation questionnaire is divided into six parts. The researcher compared the learners' responses to 4 parts in the high school and the private institute because these 4 parts are more related to this research.

Table 10 shows the descriptive statistics of different parts of the motivation questionnaire for each group and Figure 9 presents the graphical representation of the same results.

TABLE 10.

\begin{tabular}{cllll} 
DESCRIPTIVE STATISTICS OF DIFFERENT PARTS OF MOTIVATION QUESTIONNAIRE FOR BOTH GROUPS \\
\cline { 2 - 5 } Group & Parts of motivation & No. & Mean & SD \\
\hline School & Instrumental & 25 & 15.498 & 1.5831 \\
& Integrative & 25 & 16.212 & 4.0901 \\
& Coercion index & 25 & 14.280 & 4.7734 \\
& Attitude & 25 & 14.347 & 3.1979 \\
& Textbooks & 25 & 14.808 & 1.6036 \\
& Achievement & 25 & 14.784 & 4.5559 \\
& Instrumental & 25 & 17.046 & 1.6848 \\
& Integrative & 25 & 18.480 & 2.2683 \\
& Coercion index & 25 & 10.920 & 3.0911 \\
& Attitude & 25 & 17.270 & 3.1531 \\
& Textbooks & 25 & 15.480 & 2.9189 \\
& Achievement & 25 & 17.976 & 4.1151 \\
\hline
\end{tabular}

As this table shows the mean scores of the private institute in instrumental motivation, integrative motivation, attitude toward learning English, attitude towards English text books, and overall achievement are higher than the high school learners. The mean score of the high school learners in the coercion index is higher than the private institute.

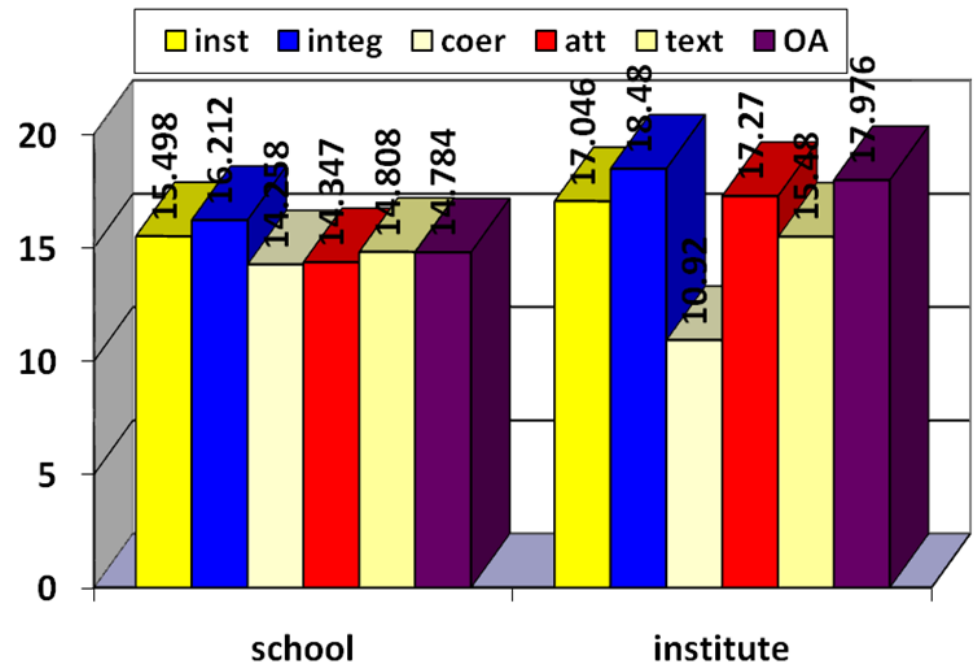

Figure 9. Graphical representation of the means in different parts of the motivation questionnaire for both groups

As figure 9 shows the mean score in each part of the motivation questionnaire for the private institute learners is higher than the high school learners except in the coercion index. 
1. The Results of the Analysis of the Learners' Responses to the First Part of the Motivation Questionnaire

The first part of this questionnaire deals with the learners' reasons for learning English. It consisted of 8 questions: 4 items ask instrumental motivation, 2 items are about integrative motivation and 2 questions are about coercion index.

The Analysis of the Learners' Responses to the Instrumental Motivation Questions

These questions of the questionnaire deal with the instrumental motivation:

1. I think it will some day help me get a good job.

2. Proficiency in English is a sign of good education.

3. I study English to go to the university.

4. English is the language of progress and modernization.

As Table 10 shows, the mean and the standard deviation of the private institute students on the instrumental motivation questions are respectively 17.04 and 1.68. The mean and the standard deviation of the high school students on the instrumental motivation questions are respectively 15.49 and 1.58. By comparing the means of the two groups shown in the table 4-10 it can be said that the amount of instrumental motivation is higher for the private institute learners. A $t$-test was applied to find out if there is a significant difference between these two groups. Table 4.11 reveals the results of this $t$-test.

TABLE 11.

THE RESULTS OF THE T-TEST FOR THE INSTRUMENTAL MOTIVATION

\begin{tabular}{lllllll}
\multicolumn{7}{l}{ THE RESULTS OF THE T-TEST FOR THE INSTRUMENTAL MOTIVATION } \\
\hline Group & $\mathrm{N}$ & Mean & SD & df & t & $\mathrm{p}$ \\
\hline High School & 25 & 15.49 & 1.58 & 48 & -3.348 & .002 \\
Institute & 25 & 17.04 & 1.68 & & & \\
\hline
\end{tabular}

It can be seen in Table 11 that the amount of $t$-observed $(t=-3.348)$ is significant at the probability level of $\mathrm{p}=.002$ which is smaller than .05. In other words, instrumental motivation in these two settings is different. The amount of instrumental motivation is higher for the private institute learners.

The Analysis of the Learners' Responses to the Integrative Motivation Questions

These questions of the questionnaire deal with the integrative motivation:

1. I think it will help me to better understand English-speaking people.

2. I like English.

As Table 10 shows, the mean and the standard deviation of the private institute students on the integrative motivation questions are respectively 18.48 and 2.26. The mean and the standard deviation of the high school students on the integrative motivation questions are respectively 16.21 and 4.09. By comparing the means of the two groups shown in the above table it can be said that the amount of integrative motivation is higher for the private institute learners. A $t$ test was applied to find out if there is a significant difference between these two groups. Table 13 reveals the results of this $t$-test.

TABLE 13.

THE RESUlts OF THE T-TEST FOR THE INTEGRATIVE MOTIVATION

\begin{tabular}{|c|c|c|c|c|c|c|}
\hline Group & $\mathrm{N}$ & Mean & SD & df & $\mathrm{t}$ & $\mathrm{p}$ \\
\hline High School & 25 & 16.21 & 4.09 & 48 & -2.425 & .019 \\
\hline Institute & 25 & 18.48 & 2.26 & & & \\
\hline
\end{tabular}

It can clearly be seen in Table 13 that the amount of $t$-observed $(t=-2.425)$ is significant at the probability level of $\mathrm{p}=.019$ which is smaller than .05 . In other words, the amount of the integrative motivation is significantly higher for the private institute students than the high school students.

The Analysis of the Learners' Responses to the Coercion Index Questions

These questions deal with the Coercion Index:

1. It is a part of the school curriculum.

2. My parents want me to learn it.

As Table 10 shows, the mean and the standard deviation of the private institute students on the coercion index questions are respectively 10.92 and 3.09. The mean and the standard deviation of the high school students on the coercion index questions are respectively 14.28 and 4.77. By comparing the means of the two groups shown in the above table it can be said that the amount of coercion index is higher for the high school learners. In other words, high school learners attend the English classes only because it is a part of the school curriculum not because of their motivation. A $t$-test was applied to find out if there is a significant difference between these two groups. Table 15 reveals the results of this $t$-test.

TABLE 15.

THE RESULTS OF THE T-TEST FOR THE COERCION INDEX QUESTIONS

\begin{tabular}{lllllll}
\hline Group & $\mathrm{N}$ & Mean & SD & df & t & $\mathrm{p}$ \\
\hline High School & 25 & 14.28 & 4.77 & 48 & 2.954 & .005 \\
Institute & 25 & 10.92 & 3.09 & & & \\
\hline
\end{tabular}


As Table 15 shows the amount of $t$-observed $(t=2.954)$ is significant at the probability level of $\mathrm{p}=.005$ which is smaller than .05. In other words, the amount of the coercion index is significantly higher for the high school students than the private institute students.

2. The Analysis of the Learners' Responses to the Second Part of the Motivation Questionnaire

The second part of this questionnaire deals with the learners' attitude toward learning English and consisted of 5 questions:

1. Studying English is an enjoyable experience.

2. I would study English in school even if it were not required.

3. I do not like to spend my time on subjects other than English.

4. I think learning English is the best experience in my life.

5. Learning subjects other than English is a waste of time.

As Table 10 shows, the mean and the standard deviation of the private institute students on questions about learners' attitude are respectively 17.27 and 3.15. The mean and the standard deviation of the high school students on these questions are respectively 14.34 and 3.19. By comparing the means of the two groups shown in the above table it is clear that the private institute learners have positive attitude toward learning English. It can be said that learners' motivation cause positive attitude to learning English and vice versa. A $t$-test was applied to find out if there is a significant difference between these two groups. Table 4.16 reveals the results of this $t$-test.

TABLE 16

\begin{tabular}{lllllll}
\multicolumn{6}{c}{ THE RESULTS OF THE T-TEST FOR LEARNERS' } & ATTITUDE TOWARD LEARNING ENGLISH \\
\hline Group & $\mathrm{N}$ & Mean & SD & df & t & p \\
\hline High School & 25 & 14.34 & 3.19 & 48 & -3.255 & .002 \\
Institute & 25 & 17.27 & 3.15 & & & \\
\hline
\end{tabular}

It can clearly be seen that the amount of $t$-observed $(t=-3.255)$ is significant at the probability level of $\mathrm{p}=.002 \mathrm{which}$ is smaller than .05. In other words, the amount of the positive attitudes toward learning English is significantly higher for the private institute students than the high school students.

3. The Results of the Learners' Responses to the Third Part of the Motivation Questionnaire

The third part of this questionnaire deals with the learners' attitudes toward their English textbooks and consisted of 7 questions:

1. The topics and reading texts in our English textbooks are enjoyable.

2. The materials and activities in our book are interesting.

3. Reading texts and topics encourage me to read more English.

4. The pictures of the book help me to understand English better.

5. Reading passages present an up-to-date picture of the target language people.

6. Reading texts and topics are in harmony with the students own needs and interests.

7. The reading texts are interesting.

As Table 10 shows, the mean and the standard deviation of the private institute students on questions about the learners' attitude toward English textbooks are respectively 15.48 and 2.91. The mean and the standard deviation of the high school students on these questions are respectively 14.80 and 1.60. By comparing the means of the two groups shown in the above table it can be said that the private institute learners have positive attitude toward their English textbooks and this attitude can increase their motivation. A $t$-test was applied to find out if there is a significant difference between these two groups. Table 17 reveals the results of this $t$-test.

TABLE 17.

RESULTS OF THE T-TEST FOR LEARNERS' ATTITUDE TOWARD ENGLISH TEXTBOOKS

\begin{tabular}{lllllll}
\multicolumn{7}{c}{ RESULTS OF THE T-TEST FOR LEARNERS' } \\
\hline Group & $\mathrm{N}$ & Mean & SD & df & $\mathrm{t}$ & $\mathrm{p}$ \\
\hline High School & 25 & 14.80 & 1.60 & 48 & -3.176 & .003 \\
Institute & 25 & 15.48 & 2.91 & & & \\
\hline
\end{tabular}

As Table 17 shows the amount of $t$-observed $(t=-3.176)$ is significant at the probability level of $\mathrm{p}=.003$ which is smaller than .05. In other words, the amount of the positive attitudes toward English textbooks is significantly higher for the private institute students than the high school students.

4. The Results of the Learners' Responses to the Fourth part of the Motivation Questionnaire

This part, consisted of one question, asks learners' satisfaction with their achievement in English:

1. I am satisfied with my achievement in English.

As Table 10 shows, the mean and the standard deviation of the private institute students on overall achievement are respectively 17.97 and 4.11. The mean and the standard deviation of the high school students on this question are respectively 14.78 and 4.55 . By comparing the means of the two groups shown in the above table, the private institute learners are more satisfied with their achievement in English. It can be said, there is a positive relationship between motivation and overall achievement. In other words, the higher the motivation, the higher the overall achievement, and vice versa. A $t$-test was applied to find out if there is a significant difference between these two groups. Table 18 reveals the results of this $t$-test. 
TABLE 18.

THE RESUlTS OF THE T-TEST FOR THE SATISFACTION WITH OVERALL ACHIEVEMENT IN ENGLISH

\begin{tabular}{lllllll}
\hline Group & $\mathrm{N}$ & Mean & SD & df & t & p \\
\hline High School & 25 & 17.04 & 4.55 & 48 & 2.600 & .012 \\
Institute & 25 & 17.97 & 4.11 & & & \\
\hline
\end{tabular}

It can be seen in Table 18 that the amount of $t$-observed $(t=2.600)$ is significant at the probability level of $\mathrm{p}=.012$ which is smaller than .05. In other words, satisfaction with overall achievement in English in these two settings is different. Satisfaction is higher in the private institute learners.

\section{DISCUSSION}

The First Research Question: Is the methodology used in high school different from the methodology used in English language institute in terms of teacher's role, student's role, teaching materials, teaching activities, and teaching objectives?

The analysis of the observers' responses to the checklists show in the high school teacher has the central role and she decides what to teach and how to teach. Learners are considered as receivers of information, listeners, and imitators. They do not have any role in teaching process and they just repeat new structures and new words. The only material in the high school is English text book. Teaching activities and objectives are limited to repetition of structures and vocabulary. Instead, in the private institute, teachers are not at the center of the class. They are as facilitators who help students to master on language. Besides, learners have active role and they can make new short stories and conversations. Materials in the private institute are not limited to English textbooks. Teachers use audio visual materials and realia in the class also learners can bring interesting materials that are related to their lesson. Teaching activities and objectives are not limited to different drills (question and answer drills, group work drills,...) but also mastery on language skills (listening, speaking, writing, and reading) is very important.

The Second Research Question: If the answer to the first question is positive, is there any difference between learners' motivation in the high school and the English language institute?

To answer this research question, a $t$-test was used and the results show that motivation is higher in the private institute learners than the high school learners. As it was said, teaching methodology is different in these two settings then it seems there is a positive relationship between teaching methodology and motivation. Also, Boggiano et al (1992) found that if teachers be as facilitators in the class, use interesting materials (photographs, objects,...) and give learners an active role that learners can decide what to teach and how to teach, learners motivation will increase and their test anxiety will decrease.

The Third Research Question: Does the teaching methodology have any relationship with the type of learners' motivation (instrumental and integrative)?

To answer this research question a series of $t$-tests were used to analyze the learners' answers to the motivation questionnaire. It was clear that instrumental and integrative motivations are higher in the private institute learners. They want to learn English because they want to find a good job and learning English help them to have a better understanding of English-speaking people. Private institute learners have positive attitude toward learning English and their text books. Also, they were satisfied with their achievement in English. But, in the high school, learners attended the English class because it was a part of their school curriculum. They have negative attitude toward learning English because they think learning English is a dull activity and waste of time. Learners in the high school were not satisfied with their progress in English because they just want to pass their course. It was clear that if teachers use a good teaching methodology, learners have high degree of instrumental or integrative motivation.

A previous study by Giles and Coupland (1991) found that integrative and instrumental motivations are very useful factors to engage learners in learning process. Integrative motivation comes from the learner and it has a very strong power to move learners toward learning. Also, if learners want to have a good position and a good job in their society they are engaged in learning process. The result of Giles and Coupland's research is similar to the results of the present study. Then, it seems that instrumental and integrative motivations are useful factors to engage learners in learning process.

\section{REFERENCES}

[1] Adamson, H. D. (1988). Variation theory and second language acquisition. Washington, DC: Georgetown University Press.

[2] Bakhshi, Ali. (1997). Problems of teaching foreign languages in Iran. Teacher and School Quarterly, 1, 14-16.

[3] Bandalos, D., Yates, K., \& Thorndike-Christ, T. (1995). Effects of math self-concept, perceived self-efficacy, and attributions of failure and success on test anxiety. Journal of Educational Psychology, 87, 611-623.

[4] Bateni, M. R. (1991). Language and thought. Tehran: Moaser Publications.

[5] Boggiano, A. K., Shields, A., Barrett, M., Kellam, T., Thompson, E., \& Simons, J. (1992). Helpless deficits in students: The role of motivational orientation. Motivation and Emotion, 16(3), 271-296.

[6] Brindly, G. (1989). The role of needs analysis in adult ESL program design. In E. Bada \& Z. Okan (Eds.), Students language learning preferences TESL - EJ, 4/3: A-1.

[7] Brown, H. D. (2000). Teaching by principles: An interactive approach to language pedagogy. New York: Pearson Education. 
[8] Celce-Murcia, M. (1991). Teaching English as a second or foreign language. Massachusetts: Heinle \& Heinle Publishers.

[9] Chastain, K. (1988). Developing second language skills: Theory to practice. Chicago: Rand McNally.

[10] Cook, V. (2001). Second language learning and language teaching. London: Edward Arnold.

[11] Crooks, G., \& Schmidt, R. W. (2000). Motivation: Reopening the research agenda. Language Learning, 41, 469512

[12] Csizér, K., \& Dörnyei, Z. (2005). The internal structure of language learning motivation and its relationship with language choice and effort. The Modern Language Journal, 89, 19-36.

[13] Dadkhah, (2002). The relationship between test anxiety and sex. Unpublished master's thesis, University of Khoramabad, Khoramabad, Iran.

[14] Davies, A. (2006). The handbook of applied linguistics. Blackwell publishing.

[15] De Corte, E. (1993). Learning theory and instructional science. In P. Pollari, (Ed.), Portfolios in EFL teaching in Finish upper secondary school. Engl. Teaching Forum 34. 1-2.

[16] Dendato, K. M., \& Diener, D. (1986). Effectiveness of cognitive/ relaxation therapy and study- skill training in reducing self reported anxiety and improving the academic performance of test-anxious students. Journal of Counseling Psychology, 33, 131-135.

[17] Ergene, T. (2003). Effective interventions on test anxiety reduction: A meta-analysis. School Psychology International, 24, 313-328

[18] Ferrando, P. J., Varea, M. D., \& Lorenzo, U. (1999). A psychometric study of Test Anxiety Scale for Children in a Spanish sample. Personality and Individual Differences, 27, 34-44.

[19] Gardner, R. C., \& Lambert, W. E. (1972). Attitudes and motivation in second language learning. Newbury: Massachusetts.

[20] Giles, H., \& Coupland, N. (1991). Language: context and consequences. New York: Oxford University Press.

[21] Harter, S. (1996). Teacher and classmate influences on scholastic motivation, self-esteem, and level of voice in adolescents. In J. Juvonen \& K. R. Wentzel (Eds.), Social motivation: Understanding children's school adjustment (pp. 11-42). New York: Cambridge University Press.

[22] Heaton, J. B. (1988). Writing English language tests. New York: Longman Inc.

[23] Krashen, S. (1987). Principles and practice in second language acquisition. New York: Pergamon.

[24] Kyriacou, C. (1991). Essential teaching skills. England: Basil Blackwell Ltd.

[25] Lowe, P. A., Lee, S. W., \& DeRuyck, K. A. (2004). An exploratory factor analysis of a new comprehensive measure of test anxiety: The test anxiety inventory for children and adolescents (TAICA). Unpublished Manuscript.

[26] Naveh-Benjamin, M. (1991). A comparison of training program intended for different types of test-anxious students: Further support for an information-processing model. Journal of Educational Psychology, 83, 134-139.

[27] Niezgoda, K., \& Rover, C. (2001). Pragmatic and grammatical awareness: A function of the learning environment? In K. R. Rose \& G. Kasper (Eds.), Pragmatics in language teaching (pp. 63-79). Cambridge: Cambridge University Press.

[28] Nunan, D. (1993). Syllabus design. Oxford: Oxford University Press.

[29] Oxford, R. L. (Ed.). (1996). Language learning motivation: Pathways to the new century. Honolulu: University of Hawaii Press.

[30] Richards, J. C., \& Rodgers, T. S. (2003). Approaches and methods in language teaching. Cambridge: Cambridge University Press.

[31] Richards, J. C., \& Schmidt, R. (Eds.). (1983). Language and communication. London: London Group, Ltd.

[32] Rodgers, T. (2000). Methodology in the new millennium. Forum, 36(2).

[33] Schmidt, R. (1993). Consciousness, learning and interlanguage pragmatics. In G. Kasper \& S. Blum-Kulka (Eds.), Interlanguage pragmatics (pp. 21-42). New York: Oxford University Press.

[34] Schmidt, R., Boraie, D., \& Kassabgy, O. (1996). Foreign language motivation: Internal structure and external connections. In R. L. Oxford (Ed.), Language learning motivation: Pathways to a new century (Technical Report No. 11, pp. 9-70). Honolulu: University of Hawaii, Second Language Teaching and Curriculum Center

[35] Selinger, H. W., \& Shohamy, E. (1989). Second language research. Oxford: Oxford University Press.

[36] Spielberger, C. D., \& Vagg, P. R. (1995). Test Anxiety: A transactional process model. In C. D. Spielberger (Ed.), Test anxiety: Theory, assessment, and treatment (pp. 1-14).

[37] Stipek, D., \& Ryan, R. (1997). Economically disadvantaged preschoolers: Ready to learn but further to go. Developmental Psychology, 33(4), 711-723.

[38] Stöber, J. (2004). Dimensions of test anxiety: Relations to ways of coping with pre-exam anxiety and uncertainty. Anxiety, Stress, and Coping, 17, 213-226

[39] Tateyama, Y. (2001). Explicit and implicit teaching of pragmatic routines: Japanese sumimasen. In K. R. Rose \& G. Kasper (Eds.), Pragmatics in language teaching (pp. 200-22). Cambridge: Cambridge University Press.

[40] Wentzel, K. R. (1998a). Friendships, peer acceptance, and group membership: Relations to academic achievement in middle school. Child Development, 68, 1198-1209.

[41] Wentzel, K. R. (1998b). Social relationships and motivation in middle school: The role of parents, teachers, and peers. Journal of Educational Psychology, 90, 202-209.

[42] Wine, J. D. (1980). Cognitive-attentional theory of test anxiety. In I. G. Sarason (Ed.), Test anxiety: Theory, research, and applications. (pp. 349-385). Hillsdale, NJ: Erlbaum.

Mahbube Keihaniyan was born in Najafabad, Iran in 1984. The author got her B.A degree in Teaching English from Azad University of Najafabad in 2006 and her M.A. degree in Teaching English from Azad University of Najafabad in 2009.

She works as a teacher in Azad University of Najafabad. 